\title{
Words That Can Kill: The Mugesera Speech and the 1994 Tutsi Genocide in Rwanda
}

\section{Narelle Fletcher, University of Technology Sydney}

One of the most frequently asked questions in the wake of the genocide which took place in Rwanda in 1994 has been 'how could it happen?,' or more specifically, how could it be that so many thousands of individual citizens throughout the country could be motivated to turn on their neighbours in a concerted groundswell of violence, killing them without mercy. Many of the scholars and journalists who sought to elucidate the origins of the genocide in the country's colonial and post-colonial history have highlighted the significance of the stigmatisation of the Tutsi population during this period (Prunier 1995; Braeckman 1995; Hintjens 1999; Mugesera 2004). In this connection, the introduction of identity cards by Belgian authorities in 1933, which categorically established each individual's 'ubwoko' [ethnicity], intrinsically promoted the notion that ethnic difference was an important consideration for Rwandan society. More tangibly, these cards subsequently facilitated the widespread exclusion of the Tutsi population from schools and workplaces. They were also used by genocide perpetrators in 1994 to identify their victims, to the extent that they have been regarded as tantamount to 'death warrants' (Des Forges 1999: 19).

Stigmatisation was also an essential feature of the anti-Tutsi propaganda that was disseminated from the 1950s onwards in meetings, newspaper articles and political tracts (Mugesera 1994). Among the key characteristics of this propaganda discourse was the representation of Tutsi as 'inyenzi' [cockroaches] or 'inkota' [snakes]; in other words, as vermin to be exterminated. This deliberate and systematic dehumanisation of

PORTAL Journal of Multidisciplinary International Studies, vol. 11, no. 1, January 2014.

Stigma and Exclusion in Cross-Cultural Contexts Special Issue, guest edited by Annie Pohlman, Sol Rojas-Lizana and Maryam Jamarani. 
the target race constitutes a characteristic phase in the implementation of a policy of genocide (Stanton 1996). The establishment in July 1993 of Radio Télévision Libre des Mille Collines (RTLM), the so-called 'hate radio,' saw an intensification of the rhetoric of discrimination against the Tutsi throughout the country (Chrétien 1995). Given the importance of the discourse of genocide ideologists for the implementation of mass killings on the ground, elucidating the rhetorical strategies and the specific terminology used is therefore an essential task for arriving at a more incisive understanding of how the genocide in Rwanda occurred.

Among the corpus of extant documents attesting to the elaboration of genocide ideology in Rwanda, the speech made by the well-known political figure, Léon Mugesera, on 22 November 1992 is particularly significant. Mugesera was Vice-President of the incumbent Hutu party Mouvement républicain national pour la démocratie et le développement (MRND) [National Republican Movement for Democracy and Development] in the northern prefecture of Gisenyi, which was a regime stronghold of then President Juvénal Habyarimana. In this district, in the small town of Kabaya, Mugesera delivered his speech at a party meeting attended by approximately one thousand Rwandans. However, the speech was also recorded and it reached a far more extensive audience when it was broadcast in full by the RTLM radio station in November 1993 on the first anniversary of the Kabaya meeting, only a few months before the outbreak of the genocide on 6 April 1994.

Mugesera's speech is an important document because it constitutes the earliest evidence of genocidal discourse expressed by a member of the incumbent political party in Rwanda in a public forum and, as such, it has often been regarded as offering a 'blueprint' for the practical implementation of the genocide (Hintjens 1999: 255). For the respected genocide scholar Alison Des Forges, the speech was noteworthy and was preserved in its entirety because 'its ideas and style of expression were so extreme and called forth a vigorous response from the opposition' (1999: 68). In subsequent years, the contents of the speech were the subject of intense scrutiny and heated debate within the framework of judicial proceedings spanning more than a decade that were conducted in Canada to determine whether Mugesera — who had fled to that country as a refugeeshould be deported to Rwanda to face prosecution for incitement to genocide. In that context, lexical questions regarding the precise meaning of specific terms in the original 
speech delivered in Kinyarwanda, as well as important concerns raised by its French translations were crucial elements in the decision-making process, which finally resulted in Mugesera being deported to Rwanda on 23 January 2012 to stand trial.

In this article I address three key issues raised by Mugesera's speech that provide valuable insight into the strategies involved in the elaboration and implementation of genocidal discourse. The discussion first examines significant lexical and syntactical features of the original speech in Kinyarwanda. This close textual commentary is important because since delivering the speech, Mugesera has relentlessly sought to attenuate his own personal responsibility in relation to the accusation of incitement to genocide by systematically obfuscating the meaning of his words. The second associated issue relates to the reception of the speech by its target audience. In this regard, I would argue that although the manipulative purpose of genocidal discourse may well be expressed in many instances by very direct and brutal language, it can also be formulated in more subtle and insidious ways through the implicit connotations of the terminology used. In fact, the use of polyvalent or euphemistic language can be a very effective strategy for minimising spontaneous resistance to concepts that are naturally abhorrent, thereby facilitating the assimilation of the genocidal messageperhaps even unconsciously - by the target audience for which it is intended. At the same time, the fact that this message may primarily lie in the connotations, rather than in the actual standard definition of the term(s) in question, also means that it is very easy for perpetrators and negationists to then vehemently deny that such connotations were intended, or that they even exist, as Ruth Wodak (2007) has noted in her analysis of the coded anti-Semitic discourse of an Austrian rightwing politician. It is therefore of vital importance to take into consideration the message that the target audience has retained from the discourse in question, where that information is available.

The third focus of attention in this discussion relates to cross-cultural issues of translation and interpretation raised by the legal proceedings conducted against Mugesera in Canada. The main piece of evidence in the proceedings was the text of the speech itself; the fact that it had been delivered in a language not spoken by the vast majority of those involved in the hearings was acknowledged as a serious hurdle. The impassioned debates concerning the accuracy of the different French translations of the speech in this foreign context highlighted the enormous difficulties associated with 
arriving at a clear understanding of the meaning of a text that has been lifted out of its original linguistic and sociocultural environment. It also illustrated the potential for deliberate misrepresentations of meaning by translators who may themselves be pursuing a specific agenda. Such considerations have grave repercussions not only within the very specific realm of judicial rulings on cases relating to genocide, but for genocide scholarship as a whole, in every instance where the necessity for translation creates incontrovertible linguistic 'filters' that can impact on the accuracy of the information communicated from the genocide survivor or witness to the genocide scholar, and indeed to the broader international community.

\section{Lexical and syntactical features of the original speech in Kinyarwanda}

Léon Mugesera was a skilled orator who was cognisant of the spoken word's potential power. The speech he made in Kabaya in 1992 is lengthy: its delivery took roughly thirty minutes and the transcription of the original Kinyarwanda text amounts to some three thousand words. There is a discernible structure and each section is explicitly signposted for the listeners. Brief introductory remarks (110 words) identify four main points which the speaker will develop: the importance of being wary of alleged proTutsi political parties within Rwanda such as the Mouvement démocratique républicain (MDR) [Republican Democratic Movement]; the importance of not allowing the country to be 'invaded' by the Tutsi; the necessity for his listeners to protect themselves against the Tutsi; and finally, the behaviour they should adopt. The main body of the speech contains detailed argumentation addressing each of these main points in order (2700 words). This section is also characterised by frequent recourse to many rhetorical strategies to sustain the audience's attention and to facilitate their understanding. These include lexical and syntactical repetitions, inclusive terminology ('we,' 'us'), instructional language ('we must not let ourselves be invaded!'/'unite!'), humour in the form of mockery of political opponents, rhetorical questions, and the use of logical connectors ('first,' 'second,' 'next'), which create the impression of a well-organised and well-argued presentation. The speech ends with a clearly labelled conclusion (150 words) comprising a brief recapitulation of its key points.

The target audience of the speech is identified in Mugesera's opening lines as the faithful followers of the party_'Abarwanashyaka ba Muvoma yacu' [lit. militants of our movement] — and Mugesera repeatedly exploits the rhetorical devices of empathy 
and identification to reinforce the notion of unity amongst the assembled group. The MRND is symbolically represented as an extension of the family unit: Mugesera addresses his listeners throughout as 'babyeyi, bavandimwe' [parents, brothers]. He also employs the term 'urugo' - the traditional enclosure surrounding the family home - to promote the notion of homogeneity between family, political party and country. The first mention of this word appears in a deliberately shocking metaphor for the conflict between the MRND-led Hutu majority and their political opponents who supported the Rwandan Patriotic Front (RPF), the Tutsi political party in exile:

Mbe wa mugabo we, nawe wa mubyeyi we muri hano, harya umuntu azaza yicare mu rugo rwawe, ahannye, wongere wemere ko ahagaruka koko?!? Uwo ni umurizo rwose! (Le Discours de Kabaya 1992: 5) ${ }^{1}$

Hey, you, man and you, woman who are here, if someone comes and sits in your enclosure and defecates, will you really allow him to return? That is totally taboo. ${ }^{2}$

In these lines, the Hutu are portrayed as being 'at home.' Their country Rwanda is both a physical space and a patriotic concept that it is their right and duty to defend. The Tutsi on the other hand are represented as outsiders who abuse the hospitality of the rightful owners and transgress all social mores by defecating. Tolerating such blatantly hostile behaviour is untenable: indeed, Mugesera categorically states that it is 'umuziro' [taboo]. By choosing this term, the orator introduces the connotation that such tolerance is not only unacceptable, but prohibited by the moral code underpinning the society. From this perspective, repelling the Tutsi is no longer simply a political or even an ethnic question. Instead, it is framed as a moral imperative to preserve the home[land]. This message is reiterated a few paragraphs later using a combination of the two powerful terms of 'urugo' and 'umuziro': 'urugo rwacu ntiruvogerwa. Kuvogerwa rero mumenye ko ari umuziro!' (6) [our enclosure is not allowing itself to be invaded. Know that to allow oneself to be invaded is taboo!].

Many scholars have commented on the hierarchical nature of Rwandan society, identifying it as one of the key factors that contributed to the successful implementation of the genocidal agenda advocated by the Hutu extremists (Kellow \& Steeves 1998: 116). However, a frequently made assumption is that the participation of thousands of Rwandans in the mass killings of the Tutsi stemmed from a basic ingrained response

\footnotetext{
${ }^{1}$ All number references to Mugesera's speech relate to the section divisions used in the online text that is accompanied by the French translation by Thomas Kaminzi. All highlighting in bold is mine.

${ }^{2}$ All translations from Kinyarwanda and French are mine unless otherwise specified.
} 
tantamount to blind obedience. In this regard, Mugesera's speech is a particularly valuable document in illustrating the level of sophistication of the orator's message. In order for the speech to be effective, it was not sufficient for Mugusera to recite slogans or to give his audience blunt directives to eliminate the Tutsi. Instead, he presents a cleverly constructed argumentation that has the appearance of being firmly grounded in Rwandan law and Rwandan social traditions. He cites authoritative texts such as the 'Ivanjili' [the gospel] in order to bolster the credibility of his arguments. However, these references are then subjected to manipulation and distortion to align them more convincingly with Mugesera's own agenda with regard to the Tutsi. For example:

\footnotetext{
Mw'Ivanjili biranditse ngo'ko: 'Nibagukubita urushyi kw'itama limwe uzatege ilindi bakubite ho.' Njye mbabwiye ko iyo Vanjili yahindutse muri muvoma yacu: nibagukubita urushyi kw'itama limwe, uzabatere ebyili ku rindi hanyuma biture hasi ubutazazanzamuka! (Le Discours de Kabaya 1992: 5)

In the gospel it is written: 'If someone slaps you on the cheek, give the other one so he can hit it as well.' I am telling you that this gospel has changed in our movement. If someone slaps you on the cheek, hit him twice on the other so he will fall to the ground and will not able to regain consciousness.
}

On one level, this revised ending can be read simply as an illustration of the idea that the Hutu must take action to defend themselves against Tutsi aggression. However, Mugesera's lexical choice of the term 'ubutazazanzamuka' [literally, so that he will not be able to come out of his unconscious state] could also be interpreted as a euphemism to convey the idea that these opponents should indeed remain permanently inanimate on the ground - in other words, that they should be killed. This is an example of the point raised earlier with regard to the importance of elucidating the connotations of a given term, and there are a number of other instances of potentially polyvalent language throughout the speech. Whether or not this was the actual meaning Mugesera wished to convey is a pivotal question, as the onus of establishing intent is one of the core requirements in any judicial prosecution for genocide.

A significant stylistic feature of the Kabaya speech is Mugesera's use of rhetorical questions. This is a powerful syntactical device used to engage the audience's attention, but it can also fulfil a persuasive function by orientating the audience's opinion in a specific direction. The most remarkable use of this linguistic strategy in Mugesera's speech can be found in an accumulation of questions regarding families within Rwanda who actively support the Tutsi cause. It is also here that the core genocidal verb 'gutsemba' [to exterminate] is used for the first time: 
Kuki abo babyeyi bohereje abana batabafata ngo babatsembe? Kuki badafata abo babajyana na bo bose ngo babatsembe? Ubu mutegereje ko bazaza kudutsemba koko?!? (Le Discours de Kabaya 1992: 9)

Why don't we seize those parents who sent their children and exterminate them? Why don't we seize all those who bring them and exterminate them all? Are we really waiting now for them to come and exterminate us?

The syntactical structure of these lines with their question format, further enhanced by repetition, carries the strong communicative force of a suggestion. It is therefore difficult not to see these words as an explicit call for the extermination of the Tutsi and their supporters, especially against the backdrop of the widespread denigration of the Tutsi as 'inyenzi' [cockroaches] that should be stamped out. This term is omnipresent in Mugesera's speech, appearing more than twenty times, whereas the standard designation of 'Abatutsi' is used only once. Mugesera's preference for the derogatory term illustrates the extent to which the stigmatisation of the Tutsi was already an ingrained component of the discourse of genocide ideologists in the early 1990s.

\section{Reception of the speech by its target audience}

Mugesera's stated purpose in addressing the audience at Kabaya was to instruct them as to how they should behave. This speech was therefore intended to have a lasting impact on the audience: to this end, it was important that crucial elements remain in the minds of the listeners long after the end of the meeting. Among the most powerful and memorable features of the speech are the singular images that Mugesera uses to provoke a hostile reaction to the Tutsi and their supporters. The first of these images, that of the Tutsi defecating in the Hutu family enclosure discussed above, comes very early in the speech. It is a deliberately shocking picture that Mugesera plants in the minds of his listeners in order to illicit an emotional as well as an intellectual response to his argumentation. However, another image has acquired such notoriety that it is often cited as an example of genocidal discourse in studies devoted to the genocide in Rwanda (Melvern 2006: 39). This section of the speech comes well after the explicit call to exterminate discussed above, but it can be seen as an equally overt incitement to action:

\footnotetext{
Mperutse kubwira umuntu wali unyiraseho ngo ni za PL. Ndamubwira nti: 'ikoza twakoze muli 59, nubwo nali umwana, nuko twabaretse mugasohoka.' Mubaza niba atarumvishe inkuru y'abaFalasha, basubiye iwabo muli Israyeli bavuye muli Ethiopiya ambwira ko atayizi, nti: 'Ntabwo uzi kwumva no gusoma? Jye ndakumenyesha ko iwanyu ali muli Ethiopiya, ko tuzabanyuza muli Nyabarongo mukagera yo bwangu’! (Le Discours de Kabaya 1992: 17) pro-Tutsi]: 'The mistake we made in 1959, even though I was a child then, was that we let you
} 
leave.' I asked him if he hadn't heard the story of the Falashas who returned to their home in Israel from Ethiopia? He said he did not know this story. I said to him: 'Don't you know how to listen or read? Let me tell you that your home is in Ethiopia, and that we will send you back along the Nyabarongo river so you get there quickly.'

Here Mugesera exploits the stylistic device of reproducing an alleged exchange in direct speech to endow the thematic content with the natural dynamics inherent in the communicative speech act of a conversation. At the same time, it could also be argued that through the use of the dialogue format, Mugesera is effectively modelling the type of behaviour he wishes his listeners to emulate: in other words, when they encounter Tutsi or their supporters, they should tell them they will send them back to Ethiopia. Moreover, the fact that Mugesera uses the simple future tense 'tuzabanyuza' [we will send you] without any modalisation such as 'could' or 'would' to attenuate the force of the verb endows this passage with the cognitive value of an incontrovertible action.

Mugesera precedes the evocation of the river by making reference to Rwandan history and the specific date of 1959. It can be assumed that everyone present at the meeting in Kabaya would have immediately grasped the full significance of Mugesera's mention of both 1959 and the Nyabarongo river. At the 1998 immigration hearing in Canada, however, it was necessary to call on expert witnesses to bridge the sociocultural gap in knowledge between the two audiences. In this specific instance, the Belgian academic Filip Reyntens explained that 1959 marked the end of the Tutsi monarchy and the beginning of the revolution leading to the formation of a government led by the Hutu majority. During this period many thousands of Tutsi fled the country. Another expert witness, Alison Des Forges, provided the information that during previous massacres, Tutsis had been killed and their bodies thrown into the Nyabarongo river (Mugesera $\mathrm{c}$. Canada 1998: 75). A significant detail in this connection is that the Nyabarongo river is not navigable because it is too shallow: for this reason, the suggestion that Mugesera's words may refer to sending the Tutsi back to Ethiopia by boat is not credible. Such contextual information is essential in order to fully appreciate the significance of Mugesera's words. The orator was effectively anchoring his argumentation in behaviour that had been validated by its status as part of Rwandan history. However, the lasting impact of the reference to Nyabarongo can also be explained by the fact that it evokes a simple and powerful visual image - that of Tutsis floating away along the river. 
The extent to which Léon Mugesera was successful in communicating the essential ideas contained in his genocidal discourse is illustrated by the testimonies of a number of the audience members who were present at the Kabaya meeting. The interviews were conducted by the Rwandan media in early 2012 to record the reaction of Rwandans to Mugesera's return to face trial in Kigali. Of course, reservations have to be expressed regarding the reliability of these statements, given that the interviews were conducted some twenty years after the speech was delivered, and that the content of the interview may have been distorted by the editing process. However, it appears useful to note that each of the audience members interviewed had retained a very similar message from Mugesera's speech. Thus, for Aisha Mukantagara, who is identified as a Tutsi:

\begin{abstract}
Ubwo inkuru ya mbere yatangiye kuvuga ngo Abatutsi ngo babajyane muri Ethiopiya ngo babanyuze muri Nyabarongo ngo bahinguke iwabo muri Ethiopiya. Ubwo noneho, ubwo interahamwe aho zari ziri zaje kubyina zaje kugira gute... noneho ziratangira zikajya zikurebano undi muntu mo abandi bantu ahari. Zikavuga ngo aho ngo ntimubyumvise ngo murabatahana mubajyana hehe? (Léon Mugesera speech /eye witness testimony 2012)
\end{abstract}

The first news he announced was that the Tutsi should be sent to Ethiopia by sending them along the Nyabarongo so that they would come out in Ethiopia. After that, the interahamwe [militia responsible for widespread killing during the genocide], who had come there to dance, started to look at us differently as if we were different people. They asked us: did you hear what was said and should you be allowed to go back anywhere?

The testimony of Fayza Hakizimana that appears in the same broadcast contains more details regarding the emotional impact of Mugesera's words on his listeners. In introducing this new witness, the reporter comments in a voiceover that Hakizimana was directly influenced by Mugesera's speech to take action, and that he had immediately started hunting and killing Tutsi:

\footnotetext{
Yavuze amagambo akomeye cyane ndetse bamwe kuburyo imitima yahungabanye cyane abwira akangurira Abahutu ko nibadaca Abatutsi amajosi ngo babanze kuyabaca aribo bazayabaca. Ijambo yavuze ryateye abantu benshi impungenge kuburyo yaneruye akavuga ati. Abo batutsi ni ukubanyuza iyubusamo muri Nyabarongo bagahinguka iwabo muri Ethiopiya. (Léon Mugesera speech/eye witness testimony 2012)
}

He said very harsh things so much so that the hearts of some people were hurt. He woke up the Hutu, saying that if they do not cut the necks of the Tutsi it will be the Tutsi who will cut theirs. The speech he said made a lot of people worried because he clearly said to send the Tutsis along the Nyabarongo as a shortcut back to their home in Ethiopia.

As can be seen in both of these extracts, Mugesera's words concerning the Nyabarongo river made a profound impression on his listeners, with the implicit message that the Tutsi should be killed being clearly understood. The fact that over a thousand Tutsi were indeed thrown into the Nyabarongo river in 1994 attests at the very least to how 
accurately Mugesera's words presaged these future events, if not to how effectively his words were translated into deeds (Melvern 2000: 189; Mutesi 2010).

The problem of clearly discerning the explicit and implicit meanings of the language used by Léon Mugesera lies at the heart of the ongoing controversy that has surrounded the speech. In his opening lines Mugesera acknowledges the fact that he feels he is among faithful supporters, and for this reason: 'twese uko duteraniye hano, ngirango ijambo ndi buvuge muranyunva' (Le Discours de Kabaya 1992: 2) [as we are all together here, I believe that you will understand the speech that I am going to say]. Mugesera's language can be seen as deliberately opaque: his purpose was to use his rhetorical skill to entertain and instruct his listeners, who were accustomed to extracting the underlying essential message embedded in proverbs, sayings and 'umugani,' the tales from traditional folklore. Whether or not an unequivocal causal link can be established between the contents of Mugesera's speech in 1992 and the killing of thousands of Tutsis in 1994 is a question still debated today within the legal context of the trial for incitement to genocide currently being conducted against Léon Mugesera in Rwanda. However, the Supreme Court of Ottawa did note in its 2005 ruling on the Mugesera case that the nature of the target audience was an 'important contextual factor' and that it was essential to consider how Mugesera's speech would have been understood by that audience in relation to the sociopolitical events of the time (Mugesera c. Canada 2005: 61).

\section{The speech in translation}

The 'afterlife' of Mugesera's speech within the framework of the judicial proceedings in Canada provides an invaluable insight into how crucial the translation process can be for accurately conveying the ideas that were expressed in a language few people master outside of the Rwandan community. Indeed, the fact that much of the source material relating to the genocide - printed media, radio broadcasts, testimonies by perpetrators and survivors - has been formulated solely in Kinyarwanda means that it remains inaccessible to foreign commentators until it is translated. In the International Criminal Tribunal for Rwanda (ICTR), challenges relating to the accuracy and ethical standards of the work of translators and interpreters are frequently made; however, few genocide scholars have explicitly questioned the potential impact of this inescapable linguistic filter on the information that is acquired. Closer examination of the two translations of 
Mugesera's speech that were proposed for the hearings in Canada therefore provides a valuable illustration of the potential significant distortions of meaning that may occur in the translation process, and hence of the desirability of independent verification.

The Canadian hearings were conducted in French and two very different French translations of the speech were proposed for use as the basic reference text. Mugesera's defence team submitted a translation by Rwandan linguist Eugène Shimamungu, while the legal team representing the Canadian Minister of Citizenship and Immigration preferred the translation by another Rwandan linguist, Thomas Kaminzi.

Even a cursory comparative examination of both of the French translations immediately exposes significant differences in content that cannot simply be attributed to the personal preferences of the translator regarding terminology or syntax. At this point, it is important to recall that among the core ethical responsibilities of a professional translator, the principles of accuracy and impartiality are paramount in order to ensure that the translation reflects the sense of the original text as closely as possible. Shimamungu's translation is remarkable in that it contains so many examples of what can be classified as mistranslations. In other words, the French version he proposes so significantly differs from the original that it is clearly not an accurate representation of the original text and its meaning. Given the linguist's experience and reputation, it is evident that such remarkable divergence is not the result of human error or ignorance. Rather, it suggests a deliberate intention to achieve two specific and related objectives: first, to attenuate the force of Mugesera's vilification of the Tutsis in order to minimise the risk of it being interpreted as incitement to genocide; and second, to exaggerate the threat represented by the Tutsi and their supporters in order to bolster Mugesera's claims that he was simply advocating legitimate defence. An illustrative example of the latter occurs in the early part of the speech. In the original Kinyarwanda, the orator evokes the 'death throes' of the opposing MDR party and mocks their feeble 'kicks' against his own ruling MRND party. However, in Shimamungu's version the MDR is portrayed very differently, both through the deliberate lexical choices made in translating Mugesera's words, and also by the addition of the text highlighted below, which does not appear at all in the original. The Kaminzi translation is also included here for comparison: 
Mugesera: MDR n'amashyaka bifatanyije bilimo gusamba, umugeli wabyo, muwilinde [The MDR, together with the other parties, are on the point of death. Be careful of their kicks.] (Le Discours de Kabaya 1992: 4)

Kaminzi: Le MDR et les partis qui partagent ses opinions sont en train d'agoniser. Evitez leurs coups de pied. [The MDR and the parties that share their opinions are in the process of dying. Avoid their kicks.]

Shimamungu: Le M.D.R. et les partis acolytes sont tourmentés par un désir ardent de pouvoir. Défendez-vous contre leur agression. [The MDR and the associated parties are tormented by an ardent desire for power. Defend yourselves against their aggression.] (Discours attribué au Dr. Mugesera: 2)

Compared with Mugesera's original intention, which was clearly to denigrate the political strength of the opposing parties by dismissively comparing their actions to the feeble kicks of a dying man, Shimamungu's version reads as being totally contradictory to the original text. This can only be attributed to the translator's pursuit of a very different agenda as dictated by the new context of the Canadian judicial hearing.

However, by far the most blatant example of a mistranslation in Shimamungu's text occurs in relation to the key verb ' $g u t s e m b a$ ' [to exterminate] in the passage discussed above. The impression that the translator's overriding objective is to mitigate the violence of Mugesera's language directed against the Tutsi, rather than to faithfully translate the original Kinyarwanda text, is incontrovertible. Thomas Kaminzi’s French translation is also included here for the purposes of comparison:

\footnotetext{
Mugesera: Kuki abo babyeyi bohereje abana batabafata ngo babatsembe? Kuki badafata abo babajyana na bo bose ngo babatsembe? Ubu mutegereje ko bazaza kudutsemba koko?!? (Le Discours de Kabaya 1992: 9) [Why don't we seize those parents who sent their children and exterminate them? Why don't we arrest all those who bring them and exterminate them all? Are we really waiting now for them to come and exterminate us?]

Kaminzi: Pourquoi n'arrête-t-on pas ces parents qui ont envoyé leurs enfants et pourquoi ne les extermine-t-on pas? Pourquoi n'arrête-t-on pas ceux qui les amènent et pourquoi ne les extermine-t-on pas tous? Attendons-nous que ce soit réellement eux qui viennent nous exterminer? [Why don't we arrest those parents who sent their children and why don't we exterminate them? Why don't we arrest those who bring them and why don't we exterminate them all? Are we waiting until it is really them who come to exterminate us?]

\begin{abstract}
Shimamungu: Pourquoi ces parents qui ont envoyé les enfants au front ennemi ne les arrête-t-on pas pour les soumettre à ce jugement? Pourquoi n'arrête-t-on pas ceux qui les convoient et tous les membres de ce réseau pour les soumettre à ce jugement? [Why don't we arrest these parents who sent their children to the enemy front and why don't we subject them to this judgment? Why don't we arrest those who send them and all the members of that network in order to subject them to this judgment?] (5)
\end{abstract}

The challenge of reformulating the last of Mugesera's rhetorical questions in a way that would appear coherent with this singular interpretation of the verb 'gutsemba' was clearly deemed to be insurmountable, with the result that Shimamungu has simply 
omitted the entire last sentence from his translation. As noted earlier, after very careful scrutiny, Kaminzi's translation, not Shimamungu's, was retained as the official version used in all the subsequent hearings in Canada, although Mugesera's defence lawyer continued to question the accuracy of this translation, claiming that it deliberately and erroneously favoured 'the most violent words' (Un procès saisissant 1996).

Mugesera's own behaviour in the face of the ongoing condemnation of the speech is also worthy of comment, given that the orator has repeatedly sought to attenuate his own personal responsibility in relation to the accusation of incitement to genocide. For example, despite the existence of the audio recording of the speech where his voice is clearly identifiable, Mugesera initially denied uttering the words that were played back to him (Léon Mugesera au banc des accuses 1994). On another occasion, he claimed that although he was present at Kabaya, he had not been scheduled to speak, and was only called upon at the last minute as a replacement. His speech was therefore not a carefully prepared argument designed to promote genocidal attacks against the Tutsi, but rather an impromptu and impassioned personal reaction to recent events relating to the war against the RPF (Mugesera c. Canada 1998: 51). Mugesera adopted yet another tactic to absolve himself of responsibility after the broadcasting of his recorded speech in full by radio RTLM in November 1993. Mugesera protested that the radio journalists had edited his speech without his permission or knowledge and had transformed it into something unrecognisable in order to use it for their own purposes of genocide propaganda (Mugesera c. Canada 1998: 53-54).

In each of these instances, Mugesera's core argument in his own defence is grounded in the fundamental idea that the meaning of language is heavily influenced by context. This is of course a widely accepted sociocultural concept, and is one of the basic tenets of critical discourse analysis underpinning this article (Van Dijk 1993; 2001). Mugesera sought to manipulate this notion to his own advantage by focussing on the various micro-contexts in which his speech was heard to minimise his own responsibility for his specific linguistic choices, as well as to draw attention away from the far more significant macro-context of the political situation of Rwanda in 1992. He claimed, for example, that the actual syntactical structure of his text had been edited in such a way as to grossly distort the intended meaning (Mugesera c. Canada 1998: 51), and that the original sense of the word or expression in Kinyarwanda had been lost or was being 
misinterpreted as a result of being translated into another language, such as French (Léon Mugesera au banc des accusés 1994). Such comments restrict the scope of the discussion to surface issues of omission, or equivalence of specific terminology, and neglect the underlying sociolinguistic context within which those terms acquire their full potential meaning. As has been illustrated above in the example of the information provided by expert witnesses at the Canadian hearings, the sociopolitical context in which Mugesera's speech was conceived is crucial for elucidating meaning; however, this degree of illumination was clearly not beneficial to Mugesera's cause.

\section{Conclusion}

Jean-Pierre Chrétien notes in his book on the Rwandan media of this period that many genocide ideologists and perpetrators believed that they could deliver their genocidal message with impunity because the fact they were speaking in Kinyarwanda meant that they were not open to international scrutiny (1995:16). It is therefore significant that the first detailed examination of Mugesera's speech occurred in a legal framework in a foreign country rather than within its country of origin. This created an opportunity not only for calling the individual, Léon Mugesera, to account, but also for allowing the international community to acquire a greater understanding of the very specific linguistic techniques used to win the support of the Rwandan audience.

The specific language used by perpetrators, victims and witnesses in relation to the 1994 genocide in Rwanda constitutes a crucial field of research for arriving at a clearer understanding not only of what actually occurred, but how. The stigmatisation of the Tutsi population by means of their classification, exclusion and dehumanisation paved the way for their extermination, and references to all of these are present in the speech delivered by Léon Mugesera. The illustrative features of the speech that have been discussed in this article provide important insight into how genocidal ideology was transmitted to the general Rwandan population, and stand as tangible evidence of a consciously constructed campaign to convert all listeners to the genocidal cause. In the face of the growing trend towards revisionism and negationism with regard to the genocide in Rwanda, it is imperative that the veritable intended meaning of speeches such as the one delivered by Mugesera at Kabaya not be 'lost in translation.' This is essential not only in the interests of establishing criminal responsibility and subsequently imposing the most appropriate sanctions on individuals such as Léon 
Mugesera, but also in the interests of enabling the international community to arrive at a far more accurate understanding of the unwavering and intransigent resolve underpinning the implementation of the 1994 genocide conducted against the Tutsi.

\section{Reference List}

Braeckman, C. 1995, Rwanda, histoire d'un génocide. Fayard, Paris.

Chrétien, J. P. (ed.) 1995, Rwanda: les médias du génocide. Karthala, Paris. 2010, 'Le génocide du Rwanda: un négationnisme structurel,' Hommes et Libertés, no. 151, JulySeptember. Online, available: http://www.ldhfrance.org/IMG/pdf/H_L151_International_2._Le_genocide_du_Rwanda_un_negationnisme_struc turel_.pdf [Accessed 28 October 2012].

Des Forges, A. 1999, Leave None to Tell the Story: Genocide in Rwanda. Human Rights Watch and the International Federation of Human Rights Leagues, New York.

Discours attribué au Dr Mugesera Léon MRND s/préfectur (sic) Kabaya Gisenyi le 22/09/1992, trans. E. Shimamungu. Online, available: http://www.urubuga.net/Mugesera-fr2.pdf [Accessed 04 May 2012].

Hintjens, H. 1999, 'Explaining the 1994 Genocide in Rwanda,' The Journal of Modern African Studies, vol. 37 , no. 2 : 241-286.

Kellow, C. \& Steeves, H. 1998, 'The Role of the Radio in the Rwandan Genocide,' Journal of Communication, vol. 48, no. 3: 107-28.

Le Discours de Kabaya. 1992, trans. T. Kaminzi. Online, available: http://rwanda94.pagespersoorange.fr/sitepers/dosrwand/kabaya.html [Accessed 04 May 2012].

Léon Mugesera au banc des accusés, 1994. Online, available: http://www.dailymotion.com/video/x39fu2 leon-mugesera-au-banc-des-accuses-3 news [Accessed 15 October 2012].

Léon Mugesera speech /eye witness testimony, 2012. Online, available: http://www.youtube.com/watch?v=luhbkLBlR0A\&list=FLUFkRYC6y7wZmSucjg0azQ\&feature $=\mathrm{mh}$ _lolz [Accessed 29 September 2012].

Melvern, L. 2000, A People Betrayed: The Role of the West in Rwanda's Genocide. Zed, London. 2006, Conspiracy to Murder: The Rwandan Genocide. Verso, London \& New York.

Mugesera, A. 2004, 'Evolution du racisme anti-Tutsi et sa mise en pratique au jour le jour,' Dialogue, vol. 178, April-June: 35-47.

Mugesera c. Canada (Ministre de la Citoyenneté et de l'Immigration) 1998. Online, available: http://www.scribd.com/doc/79499069/Affaire-Mugesera-Commission-de-1-Immigration-et-duStatut-de-Refugie-6-novembre-1998 [Accessed 29 September 2012]. 2005. Online, available: http://www.refworld.org/docid/470a4a6bd.html [Accessed 23 October 2012].

Mutesi, T. 2010, 'Genocide Victims Who Floated on L. Victoria to be Reburied,' ORINFOR, 26 April 2010. Online, available: http://www.orinfor.gov.rw/printmedia/topstory.php?id=789 [Accessed 27 October 2012].

Prunier, G. 1995, The Rwanda Crisis, 1959-1994: History of a Genocide. C. Hurst, London.

Stanton, G. 1996, 'The 8 Stages of Genocide.' Online, available: http://www.genocidewatch.org/images/8StagesBriefingpaper.pdf [Accessed 28 October 2012].

Un procès saisissant, celui de Léon Mugesera, 1996. Online, available: http://www.dailymotion.com/video/x3c616_un-proces-saisissant-celui-de-leon_news [Accessed 15 October 2012].

Van Dijk, T. 1993, 'Principles of Critical Discourse Analysis,' Discourse \& Society, vol. 4, no. 2: 249283. 2001, 'Discourse, Ideology and Context,' Folia Linguistica, vol. 30, no. 1-2: 11-40.

Wodak, R. 2007, 'Pragmatics and Critical Discourse Analysis,' Pragmatics and Cognition, vol. 15, no. 1: 203-225. 